\title{
CHARACTERISTICS OF LEUKOCYTES AND THROMBOCYTES OF SELECTED STURGEON SPECIES FROM INTENSIVE BREEDING
}

\author{
M. PALÍKOVÁ 1) , J. MAREŠ ${ }^{2)}$, J. JIRÁSEK ${ }^{2)}$ \\ 1)Veterinary and Pharmaceutical University, Brno \\ ${ }^{2}$ Mendel's Agricultural and Forestry University, Brno, Czech Republic \\ Received June 1, 1999 \\ Accepted October 25, 1999 \\ Abstract \\ Palíková M., J. Mareš, J. Jirásek : Characteristics of Leukocytes and Thrombocytes of \\ Selected Sturgeon Species from Intensive Breeding. Acta Vet. Brno, 1999, 68: 259-264. \\ Analysis of leukocyte and thrombocyte characteristics in Acipenser baerii, Acipenser stellatus \\ and Huso huso sturgeons at the age of about 200 days kept under intensive breeding conditions is \\ presented. The differential leukocyte count of studied fish species was of lymphocytic character \\ (68.0-73.5\% of lymphocytes), and the neutrophilic and eosinophilic granulocytes amounted to \\ Statistically significant $(\mathrm{p}<0.05)$ differences were found between individual sturgeon species \\ in morphometric characteristics of studied cells (i.e. thrombocytes, lymphocytes, neutrophilic and \\ eosinophilic granulocytes). The highest values were found in Acipenser baerii. These results are \\ in good agreement with data on the ploidy in sturgeon species under study.
} $21.8-25.1 \%$ and $3.0-4.6 \%$, respectively.

Acipenser baerii, Acipenser stellatus, Huso huso, differential leukocyte count, thrombocytes, lymphocytes, neutrophilic granulocytes, eosinophilic granulocytes

The family Acipenseridae may be divided into two groups with respect to the number of chromosomes and the amount of nuclear DNA. The first group comprises species having a large number of chromosomes $(2 \mathrm{n}=250)$. The species $A$. baerii and A. gueldenstaedti belong to this group. The second group includes, for example, H. huso, A. ruthenus, A. stellatus with lower numbers of chromosomes in their genomes $(2 \mathrm{n}=118-120)$ ( Vasily e $\mathrm{v}$ et al. 1980; Gorshkova et al. 1996; Arefjev and Nikolaev 1991). Several studies have shown correlation between the ploidy in various fish species and the red blood cell size (Arefjev and Nikolaev 1991; Flajšhans 1997; Svobodová et al. 1998).

The aim of our study was to evaluate interspecies differences in morphological characteristics of leukocytes and thrombocytes in selected sturgeon species (i.e. A. baerii, $H$. huso and A. stellatus) known for different numbers of chromosomes.

\section{Materials and Methods}

A total of 10 Acipenser baerii, 10 Huso huso and 5 Acipenser stellatus sturgeons originating from the Fishery Hluboká, Mydlovary farm were sampled (A. baerii in September, A. stellatus a H. huso early in December). All the fish used in the study were clinically healthy without any signs of disease. The fish were kept under intensive breeding conditions in flow-through troughs with controlled environment (water temperature of $20{ }^{\circ} \mathrm{C}$, water oxygen saturation over $80 \%$ ). Other hydrochemical indicator values assessed in discharge water characterise the environmental conditions suitable for intensive sturgeon culture. The fish were fed complete feeding mixtures. Basic haematological and biochemical parameters have been already published (Jirásek and Mareš 1998). Prokeš et al. (1995ab;1996) studied morphometric characteristics of these sturgeon species with respect to plastic and meristematic signs. Using morphometric characteristics these authors determined the studied species to be pure species.

Blood from the fish was sampled by cardiac puncture into a heparinised syringe (Jirásek et al. 1980) and further processed employing standard methods (S vobodová et al. 1986). Blood smears were stained according to Pappenheim and the leukocyte differential count, the longitudinal and transverse axis of leukocytes (eosinophilic granulocytes, neutrophilic granulocytes and lymphocytes) and thrombocytes were determined. No basophilic 
granulocytes were found. The above mentioned values were also measured for the cell nuclei of thrombocytes and were used for computing the surface area of individual cells. In all, we measured 100 thrombocytes with their nuclei, 100 eosinophilic granulocytes, 200 neutrophilic granulocytes and 200 lymphocytes in every sturgeon species.

The data were statistically evaluated. For the assessment of the significance of differences, ANOVA with subsequent testing by Scheffe's method was utilized. Results are presented in tables as mean and standard deviation ( SD), and variation coefficient $(\mathrm{V})$.

\section{Results and Discussion}

Length and weight characteristics of the fish analysed are given in Table 1, i. e. the total body length (TL) and the body weight (W).

Table 1

Length and weight characteristics of sturgeon species studied

\begin{tabular}{|l|c|c|c|}
\hline Species & TL $[\mathrm{mm}]$ & W [g] & Age \\
\hline & Mean \pm SD & Mean \pm SD & [day] \\
\hline Acipenser baerii & $426.30 \pm 8.30$ & $274.30 \pm 23.15$ & 206 \\
\hline Acipenser stellatus & $276.83 \pm 12.25$ & $46.59 \pm 7.17$ & 184 \\
\hline Huso huso & $347.40 \pm 26.25$ & $130.56 \pm 59.31$ & 208 \\
\hline
\end{tabular}

Figs 1 to 3 present differential leukocyte counts and relative counts of subpopulations of eosinophilic and neutrophilic granulocytes.

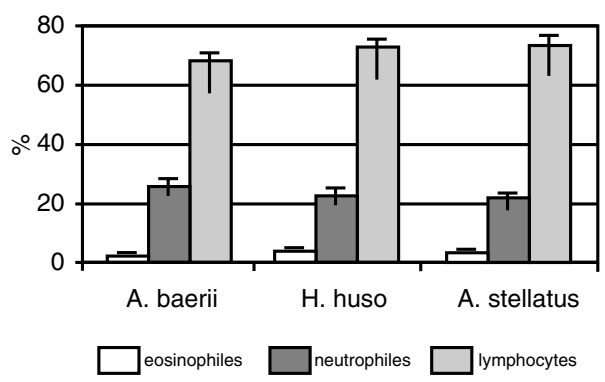

Fig. 1. Percentage of lymphocytes, cosinophilic and neutrophilic granulocytes

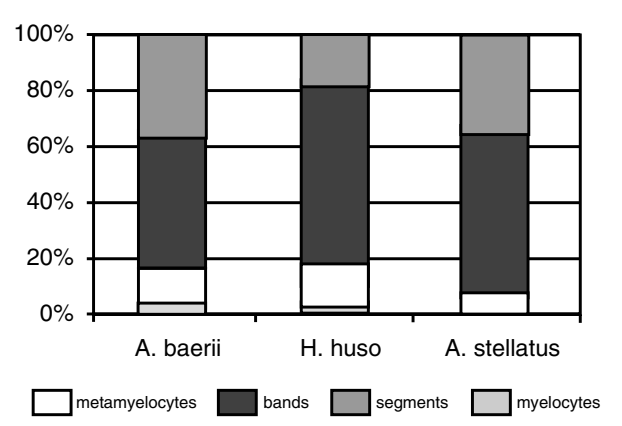

Fig. 2. Relative ratio of neutrophilic granulocyte subpopulations

Table 2 presents interspecies comparisons Comparistis species studied. Comparison of individual cell types proved in some cases differences. Greatest differences

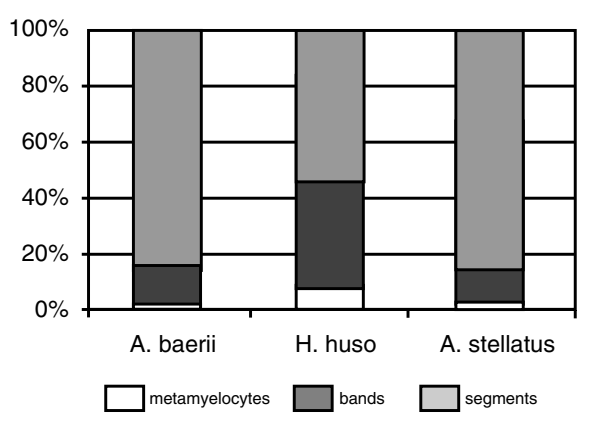

Fig. 3. Relative ratio of eosinophilic granulocyte subpopulations

The differential leukocyte counts of all three fish species were similar and of lymphocytic character $(68.0-73.5 \%)$, neutrophilic and eosinophilic granulocytes amounted to 21.8 $25.1 \%$ and $3.0-4.6 \%$, respectively. Other cell types (monocytes and developmental stages of younger granulocytes and lymphocytes - blasts, prolymphocytes and promyelocytes) occurred only sporadically $(0.7-2.0 \%)$. Compared with bony fishes, in sturgeons there was a smaller number of myelocytes and metamyelocytes and a larger number of eosinophilic and neutrophilic granulocytes with band or segmented nuclei. 
Table 2

Interspecies size comparisons of individual types of cells studied

\begin{tabular}{|c|c|c|c|c|}
\hline & & Acipenser baerii & Acipenser stellatus & Huso huso \\
\hline & & \multicolumn{3}{|c|}{$\begin{array}{c}\text { Mean } \pm \text { SD } \\
V / \% /\end{array}$} \\
\hline \multirow[t]{3}{*}{ Thrombocytes } & $\mathrm{a}(\mu \mathrm{m})$ & $\begin{array}{c}\mathbf{1 4 . 7 7 3} \pm \mathbf{2 . 1 1 3} \\
14.30 \mathrm{~B}\end{array}$ & $\begin{array}{c}\mathbf{1 2 . 7 5 1} \pm \mathbf{1 . 6 7 7} \\
13.15 \mathrm{~A}\end{array}$ & $\begin{array}{c}12.324 \pm \mathbf{1 . 3 0 5} \\
10.59 \mathrm{~A}\end{array}$ \\
\hline & $\mathrm{b}(\mu \mathrm{m})$ & $\begin{array}{c}\mathbf{6 . 3 4 6} \pm \mathbf{1 . 1 9 0} \\
18.75 \mathrm{~B}\end{array}$ & $\begin{array}{c}\mathbf{5 . 3 9 6} \pm \mathbf{1 . 1 0 0} \\
20.40 \mathrm{~A}\end{array}$ & $\begin{array}{c}\mathbf{5 . 7 7 5} \pm \mathbf{1 . 2 8 9} \\
22.31 \mathrm{~A}\end{array}$ \\
\hline & Area $\left(\mu \mathrm{m}^{2}\right)$ & $\begin{array}{c}\mathbf{7 3 . 9 2 1} \pm \mathbf{~ 1 9 . 1 2 8} \\
25.88 \mathrm{~B}\end{array}$ & $\begin{array}{c}\mathbf{5 3 . 8 6 8} \pm \mathbf{1 2 . 3 1 7} \\
22.87 \mathrm{~A}\end{array}$ & $\begin{array}{c}\mathbf{5 4 . 9 7 1} \pm \mathbf{1 2 . 1 4 8} \\
22.10 \mathrm{~A}\end{array}$ \\
\hline \multirow[t]{3}{*}{$\begin{array}{l}\text { Thrombocytes - } \\
\text { nucleus }\end{array}$} & $\mathrm{a}(\mu \mathrm{m})$ & $\begin{array}{c}10.040 \pm 1.156 \\
11.51 \mathrm{~B}\end{array}$ & $\begin{array}{c}7.813 \pm 0.752 \\
9.63 \mathrm{~A}\end{array}$ & $\begin{array}{c}7.703 \pm 0.705 \\
9.15 \mathrm{~A}\end{array}$ \\
\hline & $\mathrm{b}(\mu \mathrm{m})$ & $\begin{array}{c}\mathbf{4 . 4 9 6} \pm \mathbf{0 . 9 3 2} \\
20.73 \mathrm{~B}\end{array}$ & $\begin{array}{c}\mathbf{4 . 0 6 1} \pm \mathbf{0 . 6 4 5} \\
15.89 \mathrm{~A}\end{array}$ & $\begin{array}{c}\mathbf{4 . 1 6 3} \pm \mathbf{0 . 5 9 3} \\
14.23 \mathrm{~A}\end{array}$ \\
\hline & Area $\left(\mu \mathrm{m}^{2}\right)$ & $\begin{array}{c}35.400 \pm 8.416 \\
23.77 \mathrm{~B}\end{array}$ & $\begin{array}{c}\mathbf{2 4 . 9 3 9} \pm \mathbf{4 . 8 3 0} \\
19.37 \mathrm{~A}\end{array}$ & $\begin{array}{c}25.101 \pm 3.705 \\
14.76 \mathrm{~A}\end{array}$ \\
\hline \multirow[t]{3}{*}{ Lymphocytes } & $\mathrm{a}(\mu \mathrm{m})$ & $\begin{array}{c}9.294 \pm 1.876 \\
20.18 \text { B }\end{array}$ & $\begin{array}{c}\mathbf{8 . 4 5 7} \pm \mathbf{1 . 5 1 9} \\
17.96 \mathrm{~A}\end{array}$ & $\begin{array}{c}\mathbf{8 . 3 6 6} \pm \mathbf{1 . 2 5 3} \\
14.97 \mathrm{~A}\end{array}$ \\
\hline & $\mathrm{b}(\mu \mathrm{m})$ & $\begin{array}{c}7.683 \pm \mathbf{1 . 3 9 7} \\
18.18 \mathrm{~B} \\
\end{array}$ & $\begin{array}{c}\mathbf{6 . 5 2 1} \pm \mathbf{1 . 1 3 4} \\
17.39 \mathrm{~A}\end{array}$ & $\begin{array}{c}\mathbf{6 . 8 4 1} \pm \mathbf{0 . 9 7 1} \\
14.20 \mathrm{~A} \\
\end{array}$ \\
\hline & Area $\left(\mu \mathrm{m}^{2}\right)$ & $\begin{array}{c}\mathbf{5 7 . 4 8 4} \pm \mathbf{2 1 . 3 3 8} \\
37.12 \text { B }\end{array}$ & $\begin{array}{c}\mathbf{4 3 . 9 0 4} \pm \mathbf{1 3 . 3 6 6} \\
30.44 \mathrm{~A}\end{array}$ & $\begin{array}{c}\mathbf{4 5 . 3 6 2} \pm \mathbf{1 0 . 9 5 0} \\
24.14 \mathrm{~A}\end{array}$ \\
\hline \multirow[t]{3}{*}{$\begin{array}{l}\text { Eosinophilic } \\
\text { granulocytes }\end{array}$} & $\mathrm{a}(\mu \mathrm{m})$ & $\begin{array}{c}14.647 \pm \mathbf{2 . 3 7 5} \\
16.22 \text { B }\end{array}$ & $\begin{array}{c}13.983 \pm \mathbf{1 . 7 1 6} \\
12.27 \mathrm{~B}\end{array}$ & $\begin{array}{c}12.917 \pm \mathbf{1 . 3 2 1} \\
10.23 \mathrm{~A}\end{array}$ \\
\hline & $\mathrm{b}(\mu \mathrm{m})$ & $\begin{array}{c}12.901 \pm \mathbf{1 . 7 5 8} \\
13.63 \mathbf{B}\end{array}$ & $\begin{array}{c}\mathbf{1 2 . 5 8 5} \pm \mathbf{1 . 5 4 1} \\
12.24 \text { B }\end{array}$ & $\begin{array}{c}11.139 \pm 1.258 \\
11.30 \mathrm{~A}\end{array}$ \\
\hline & Area $\left(\mu \mathrm{m}^{2}\right)$ & $\begin{array}{c}150.883 \pm 44.264 \\
29.34 \text { B }\end{array}$ & $\begin{array}{c}139.710 \pm \mathbf{3 1 . 2 0 9} \\
22.34 \mathrm{~B}\end{array}$ & $\begin{array}{c}\mathbf{1 1 3 . 1 8 3} \pm \mathbf{1 8 . 1 9 3} \\
16.07 \mathrm{~A}\end{array}$ \\
\hline \multirow[t]{3}{*}{$\begin{array}{l}\text { Neutrophilic } \\
\text { granulocytes }\end{array}$} & $\mathrm{a}(\mu \mathrm{m})$ & $\begin{array}{c}\mathbf{1 2 . 2 2 9} \pm \mathbf{1 . 8 8 1} \\
15.38 \mathrm{AB}\end{array}$ & $\begin{array}{c}\mathbf{1 2 . 5 7 7} \pm \mathbf{2 . 2 9 2} \\
18.22 \text { B }\end{array}$ & $\begin{array}{c}11.787 \pm 1.345 \\
11.41 \mathrm{~A}\end{array}$ \\
\hline & $\mathrm{b}(\mu \mathrm{m})$ & $\begin{array}{c}\mathbf{1 0 . 7 5 6} \pm \mathbf{1 . 5 3 1} \\
14.23 \mathbf{C}\end{array}$ & $\begin{array}{c}\mathbf{9 . 3 6 5} \pm \mathbf{1 . 4 9 1} \\
15.92 \mathrm{~A}\end{array}$ & $\begin{array}{c}\mathbf{9 . 8 8 7} \pm \mathbf{1 . 2 7 9} \\
12.94 \mathrm{~B}\end{array}$ \\
\hline & Area $\left(\mu \mathrm{m}^{2}\right)$ & $\begin{array}{c}104.648 \pm 28.539 \\
27.27 \mathrm{~B}\end{array}$ & $\begin{array}{c}93.691 \pm 26.920 \\
28.73 \mathrm{~A}\end{array}$ & $\begin{array}{c}\mathbf{9 2 . 0 3 9} \pm \mathbf{1 8 . 7 5 4} \\
20.38 \mathrm{~A}\end{array}$ \\
\hline
\end{tabular}

No significant differences were found between the values indicated by the same letters. In case of their total absence in any of the examined parameters, the values are not indicated. Capitals are used for indicating the significance of differences at the level of $\mathrm{p}<0.05$ and $\mathrm{p}<0.01$, respectively.

detected in Acipenser baerii were characterised by larger cell size. Thrombocytes, their nuclei and lymphocytes of Acipenser baerii were larger in all variables as compared with $H$. huso and $A$. stellatus with high statistical significance $(\mathrm{p}<0.01)$. Neutrophilic granulocytes of $A$. baerii were larger than those of $H$. huso and A. stellatus in their longitudinal axis and surface area. Eosinophilic granulocytes of $A$. baerii differed $(\mathrm{p}<0.01)$ from $H$. huso. Comparing $H$. huso and A. stellatus, there were found differences of all studied variables of eosinophilic granulocytes and both means of neutrophilic granulocytes, but no differences in the surface area. This may be explained by a rounder shape of neutrophilic granulocytes in $H$. huso.

Table 3 presents comparisons of sizes of developmental stages of neutrophilic and eosinophilic granulocytes. Measuring eosinophilic granulocytes, no differences were found in cell sizes during the cell maturation (myelocytes - metamyelocytes - bands - segments). Statistically significant differences, however, were found in the size of various developmental stages of neutrophilic granulocytes of all the fish species studied. Greatest 
Table 3

Comparisons of surface areas of developmental stages of neutrophilic and eosinophilic granulocytes in individual fish species studied

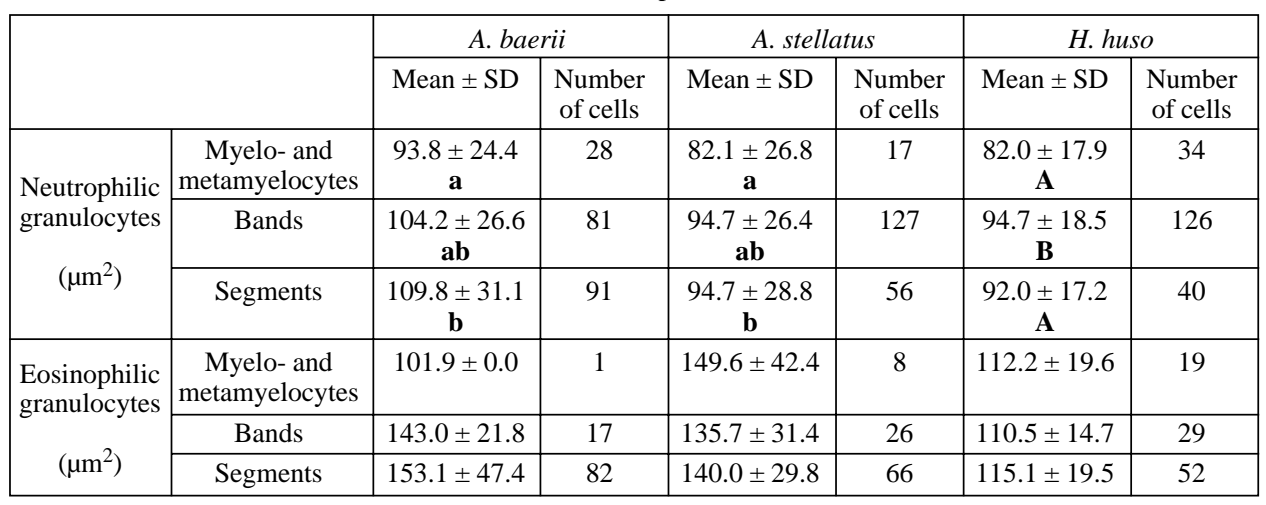

No significant differences were found between the values indicated by the same letters. In case of their total absence in any of the examined parameters, the values are not indicated. Small letters and capitals are used for indicating the significance of differences at the level of $\mathrm{P}<0.05$ and $\mathrm{P}<0.01$, respectively.

differences were in the sizes of younger developmental stages of such cells as neutrophilic myelocytes and metamyelocytes that were smaller compared to neutrophilic granulocytes with band or segmented nuclei.

Bands (46.0 - 62.9\%) and segmented neutrophilic granulocytes (19.6 - 37.6\%) were the most numerous among these cells. Eosinophilic granulocytes with segmented $(52.8-86.9 \%)$ and band (11.5- 40.7\%) nuclei occurred most frequently. The ratio of cells with band and segmented nuclei (Table 4) was species-specific. The ratio of occurrence of measured cells was similar in A. baerii and A. stellatus, whereas in $H$. huso there were larger numbers of granulocytes with band nuclei.

Table 4

The ratio between bands and segmented nuclei

\begin{tabular}{|l|c|c|c|}
\hline & A. baerii & A. stellatus & H. huso \\
\hline Neutrophilic bands / segments & 1.22 & 1.51 & 3.21 \\
\hline Eosinophilic bands / segments & 0.13 & 0.13 & 0.77 \\
\hline
\end{tabular}

Eosinophilic granulocytes showed various degrees of segmentation. The numbers of nuclear segments in individual species were different. Whereas in A. baerii (out of 92 nuclei) there prevailed nuclei with three segments ( 46 cases), two segments ( 25 cases) and four and five segments (10 and 1 cases, respectively), in A. stellatus we found no other than twosegmented nuclei. In H. huso (54 nuclei studied), mostly two-segmented (52 cases) and two three-segmented nuclei were found. In the light microscope the granules of eosinophilic granulocytes of $A$. baerii seemed finer than those of the other fish species (with largest granules in A. stellatus).

Analysis of our data revealed interspecies morphological differences of leukocytes and thrombocytes, especially larger cells in A. baerii, i.e. the species having a larger number of chromosomes. It can be therefore concluded that a dependence between the number of chromosomes and the size of leukocytes and thrombocytes exists. Similar findings were reported for the red blood cells of sturgeon-like fish species (Arefjev and Nikolaev 1991).

Haematological studies in the past concentrated mostly on the red cell component of the blood. It was only the study by Ellis (1977) that enabled the use of unified methods of 
determination and identification of individual types of leukocytes. Gershanovich et al. (1987) summarised data on haematology of sturgeon fry.

The differential leukocyte counts of analysed sturgeon species fry kept under intensive breeding conditions were characterised by relatively high numbers of lymphocytes (68-73\%). The values found in $H$. huso and A. stellatus exceeded the numbers mentioned by Pegasov (1983), Badenko a Tchichatcheva (1984). Gershanovich et al. (1987) also mention lower numbers of lymphocytes (up to 35\%) in $H$. huso fry kept under natural conditions. On the other hand, the number of monocytes $(0.4-0.6 \%)$ was lower compared with published data (Badenko a Tchichatcheva 1984).

Granulocytes were dominated by neutrophils (22-25\%), that were most frequent in $A$. baerii $(25.1 \%)$. The number of neutrophils found in $H$. huso and A. baerii was comparable with published data (Pegasov 1983, Jachnyenko 1980). Most and less frequent eosinophiles were found in H.huso (4.6\%) and A. baerii (3.1\%). Jachnyenko (1980) found the same results in fish individuals from the Lena river. Gershanovich and Kiselev (1993) have shown that the differential leukocyte count was dependent on the state of nutrition.

To our knowledge, no similar data on morphometric studies of leukocytic cells of in several sturgeon species have been published, and therefore they may be considered original findings.

\section{Charakteristika bílého krevního obrazu a trombocytů vybraných druhů jeseterů $\mathrm{z}$ intenzivního chovu}

$\mathrm{V}$ př́spěvku jsou obsaženy výsledky získané analýzou bílého krevního obrazu a trombocytů u jesetera sibiřského (Acipenser baerii), jesetera hvězdnatého (Acipenser stellatus) a vyzy velké (Huso huso) ve věku cca 200 dnů odchovávaných v podmínkách intenzivního chovu. Leukogram sledovaných druhů ryb má lymfocytární charakter (68.0 73.5\% lymfocytů), neutrofilní granulocyty tvoří $21.8-25.1 \%$ a eosinofilní granulocyty 3.0 - $4.6 \%$. Mezi jednotlivými druhy jeseterů byly shledány statisticky významné rozdíly v morfometrických charakteristikách sledovaných buněk (trombocyty, lymfocyty, neutrofilní a eosinofilní granulocyty). Nejvyšších hodnot dosahovaly buňky jesetera sibiřského. Získané výsledky korespondují s údaji o ploidii sledovaných druhủ jeseterů.

\section{References}

AREFJEV, V. A., NIKOLAEV, A. I. 1991: Cytological Analysis of the Reciprocal Hybrids between Low- and High-Chromosome Acipenserids, the Great Sturgeon, Huso huso (L.), and the Russian Sturgeon, Acipenser gueldenstaedtii Brandt. Cytologia 56: 495-502

BADENKO, L. V., CHICHACHEVA, V. P. 1984: Kriteria i metody ocenky žizněstojkostimolodi azovskich osetrovych, vypuskajemoj osetrovymi zavodami.- V kh.: Rybochozjajstvennoje značenije vnutrennich vodojemov Azovskogo i Kaspijskogo basejnov. M.: 41-55

ELLIS, A. E. 1977: The leucocytes of fish. A review. J. Fish. Biol. 11: 453-491

FLAJŠHANS, M. 1998: A model approach to distinguish diploid and triploid fish by means of computer-assisted image analysis. Acta Vet. Brno 66: 101-110

GERSHANOVICH, A. D., KISELEV, G. A. 1993: Growth and haematological response of sturgeon hybrids russian sturgeon (Acipenser gúldenstädti) x beluga (Huso huso) to protein a lipid contents in diet. Comp. Biochem. Physiol., 106A: 581-586

GERSHANOVICH, A. D., PEGASOV, V. A., SHATUNOVSKY, M. I. 1987: Ekologija i fiziologija molodi osetrovych. Moskva, Agropromizdat, $215 \mathrm{p}$.

GORSHKOVA, G., GORSHKOV, S., GORDIN, H., KNIBB, W. 1996: Karyological studies in hybrids of Beluga Huso huso (L.) and the Russian sturgeon Acipenser güldenstädti Brandt. The Israeli J. of Aquaculture 48: 35-39

JACHNYENKO, V. M. 1980: Sezonnajai vozrastnaja dinamika morfologičeskogo sostava eriferičeskoj krovi někotorich ryb oz. Bajkal. Avtoreferat kand.dissert. M. 24 p.

JIRÁSEK, J., MAREŠ, J. 1998: Hematological characteristics of juvenile sturgeons (Acipenseridae) from intensive rearing. In: Proceedings of the $4^{\text {th }}$ Ichthyohaematological Conference, Hluboká n/Vlt., Czech Republic: 14-17

JIRÁSEK, J., PRAVDA, D., HAMPL, A. 1980: An effective method of blood sampling for large scale 
hematological investigations of fish fry (Efektivní metoda odběru krve pro hromadná hematologická vyšetření rybího plůdku). Acta Univ. Agric. Brno 28: 175-182

PEGASOV, V. A. 1983: Morfofiziologičeskaja i biochimičeskaja charakteristika molodi osetrovych při vyraščivaniii $b$ iskusstvennych uslovijach. Abtoreferat dissertacii na soiskanie učenoj stepeni kandidata biologičeskich nauk.-M., $27 \mathrm{p}$.

PROKEŠ, M., BARUŠ, V., PENÁZ, M. 1995a: Morphometrical analysis of 0+ juvenile giant sturgeon (Huso huso) reared in the Czech republic for first time. Fol. Zool. 44: 269-278

PROKEŠ, M., BARUŠ, V., PEŇÁZ, M. 1995b: Morphometry of young Stellate sturgeon (Acipenser stellatus) imported to the Czech republic. Fol. Zool. 44: 349-362

PROKEŠ, M., BARUŠ, V., PEŇ́Z, M. 1996: Growth of larvae and juveniles 0+ of Siberian sturgeon (Acipenser baerii) in aquaculture and experimental conditions of the Czech republic. Fol. Zool. 45: 259-270

SVOBODOVÂ, Z., PRAVDA, D., PALÁČKOVÁ, J. 1986: Unified methods of fish hematological investigations (Jednotné metody hematologického vyšetřování ryb). Edice Metodik, VƯRH Vodňany, č. 22, 36 p.

VASILYEV, V. P., SOKOLOV, L. I., SEREBRYAKOVA, E. V. 1980: Kariotip sibirskogo osetra Acipenser Baeri Brandt reki Leny i někatoryje voprosy evoljucii kariotipov osetroobraznych. Voprosy ichtiologii 20: 814-822 
Plate X

Palíková M. et al.: Characteristics of leukocytes and thrombocytes... pp. 259-264

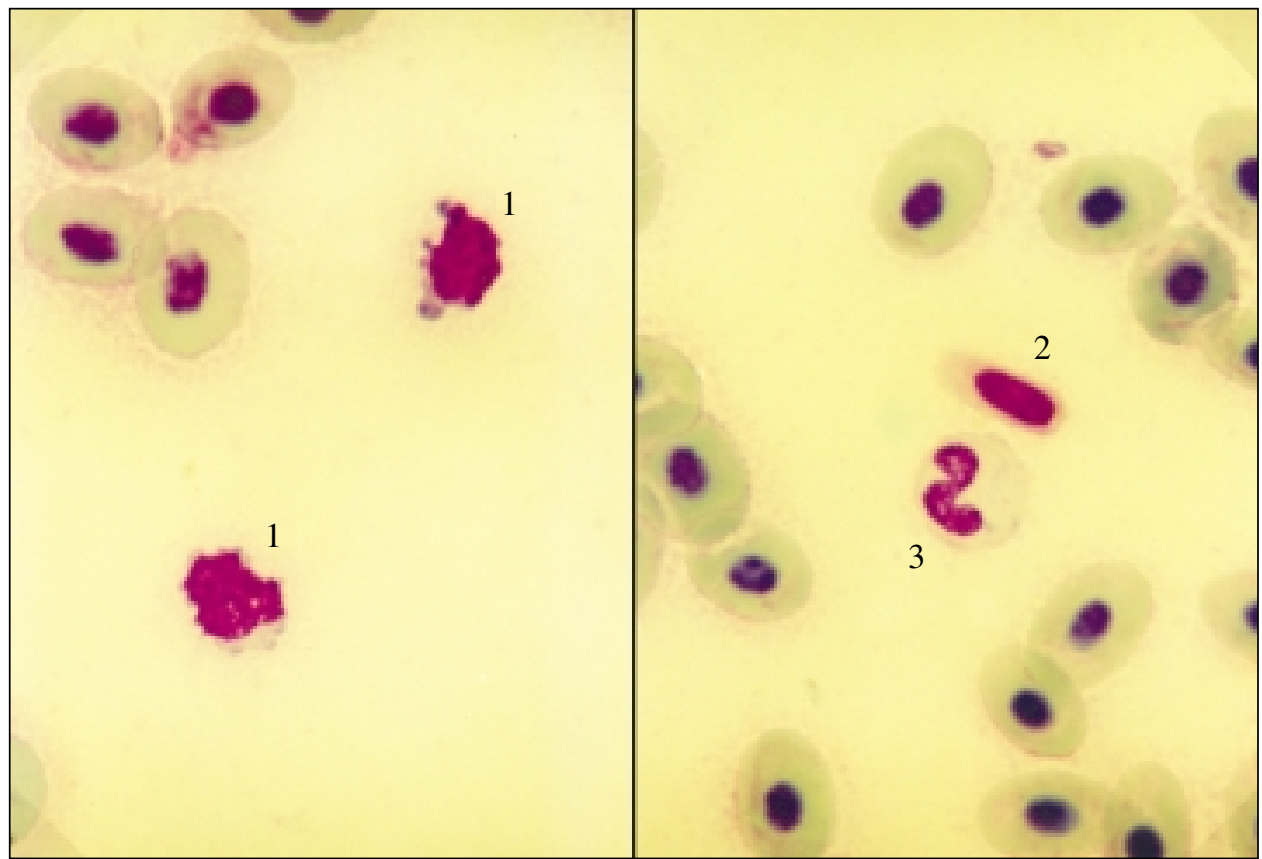

Fig. 1. Acipenser baerii. Two lymphocytes (1), thrombocyte (2) and neutrophilic granulocyte with band nucleus $(3), \times 1000$.

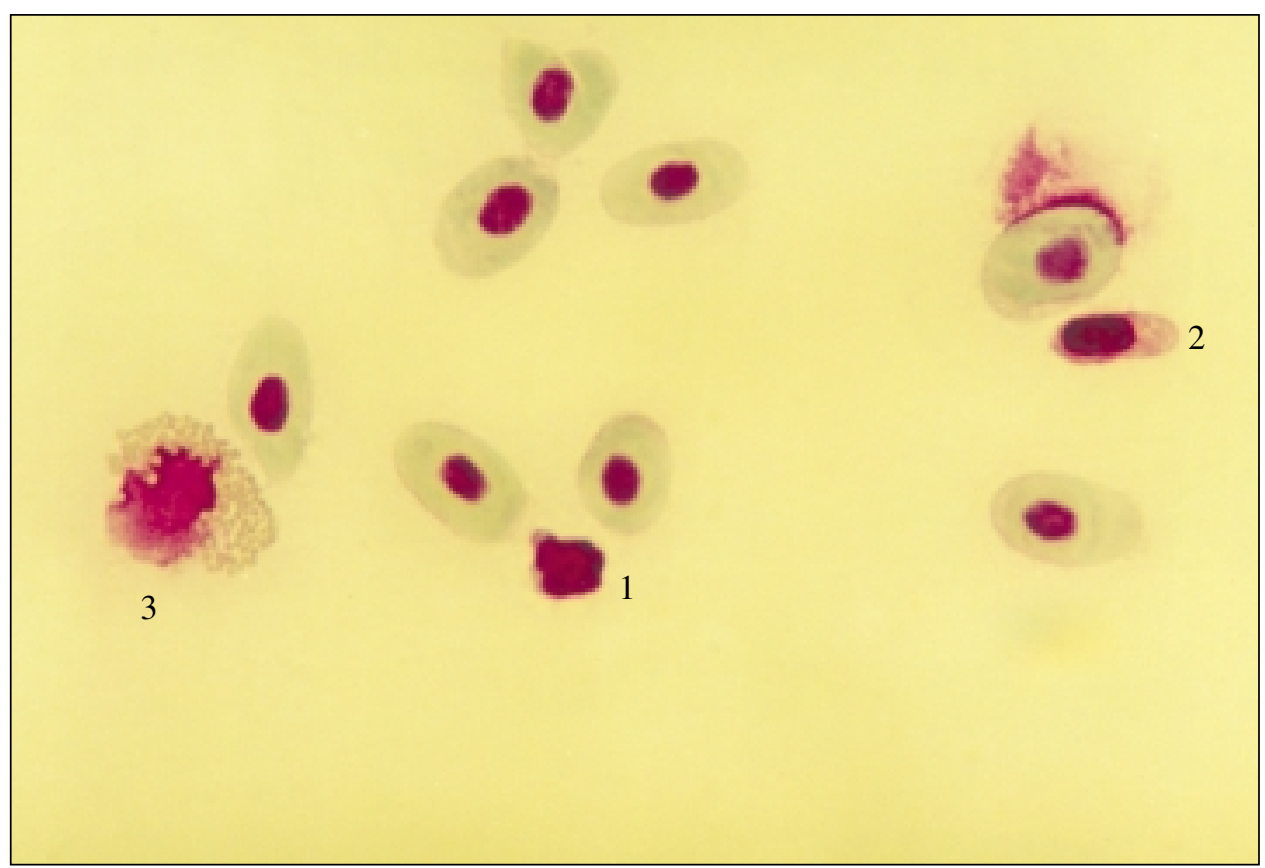

Fig. 2. Acipenser stellatus. Disintegrated eosinophilic granulocyte (3), lymphocyte (1) and thrombocyte (2), $\times 1000$. 
Plate XI

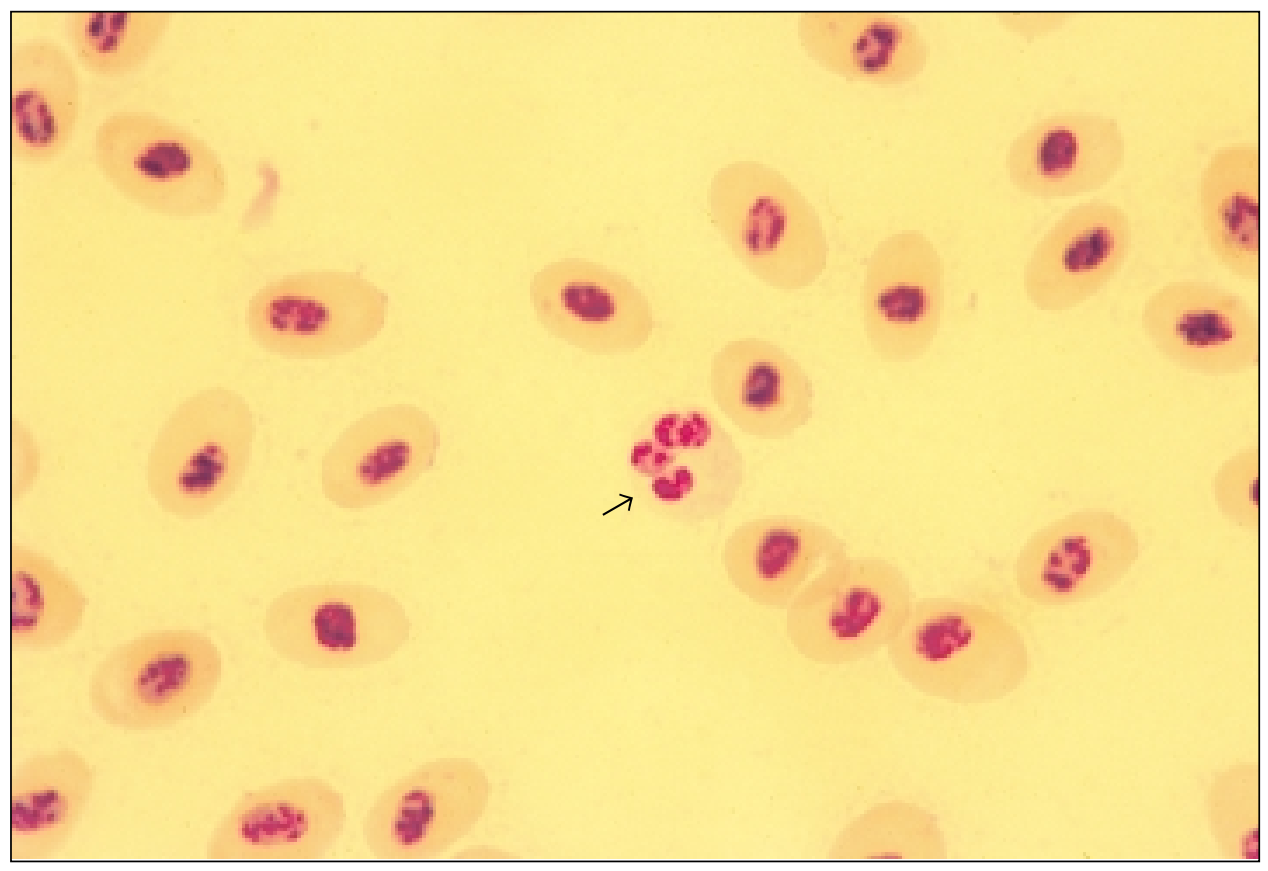

Fig. 3. Acipenser baerii. Neutrophilic granulocyte with segmented nucleus $(\rightarrow), \times 1000$.

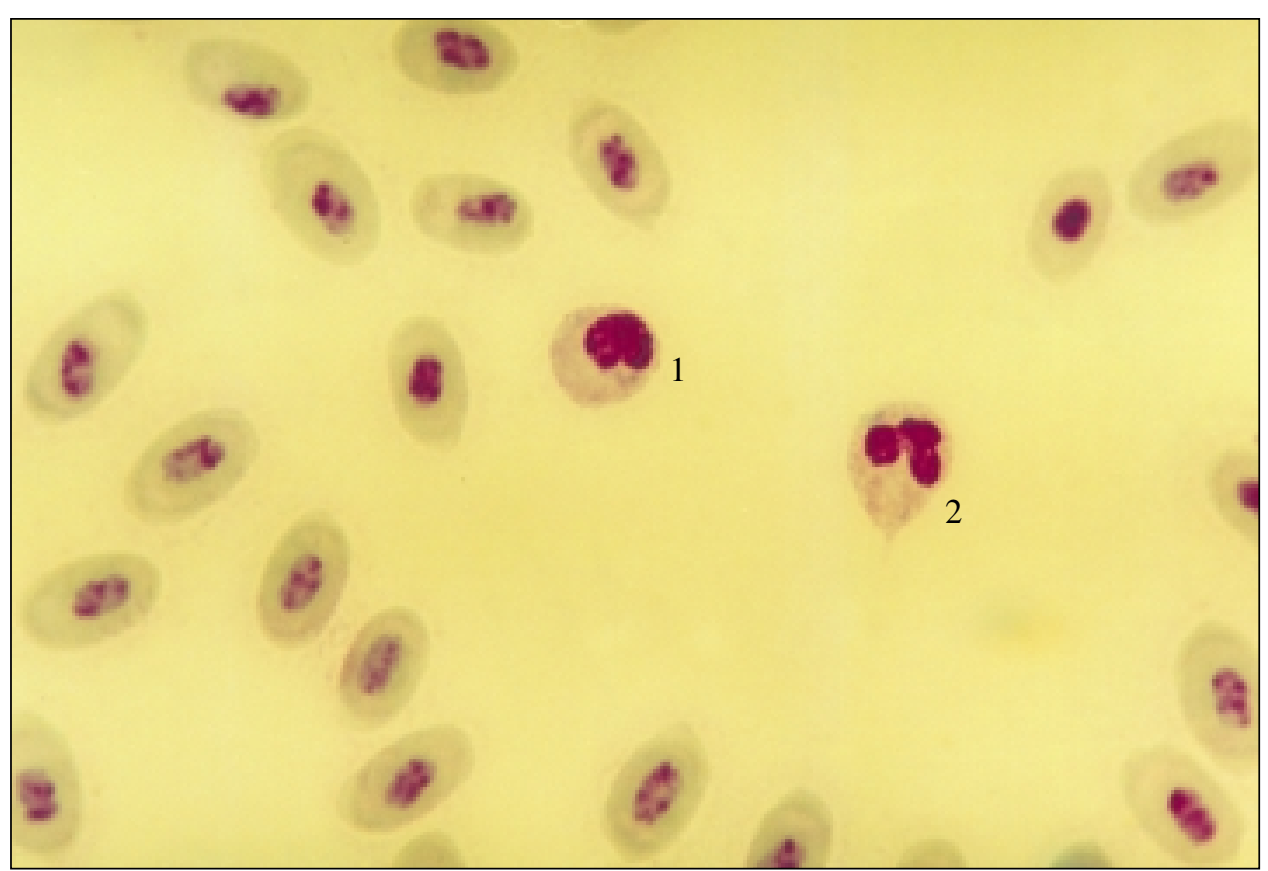

Fig. 4. Huso huso. Two neutrophilic granulocytes - with band nucleus (1) and with segmented nucleus $(2), \times 1000$. 
Plate XII

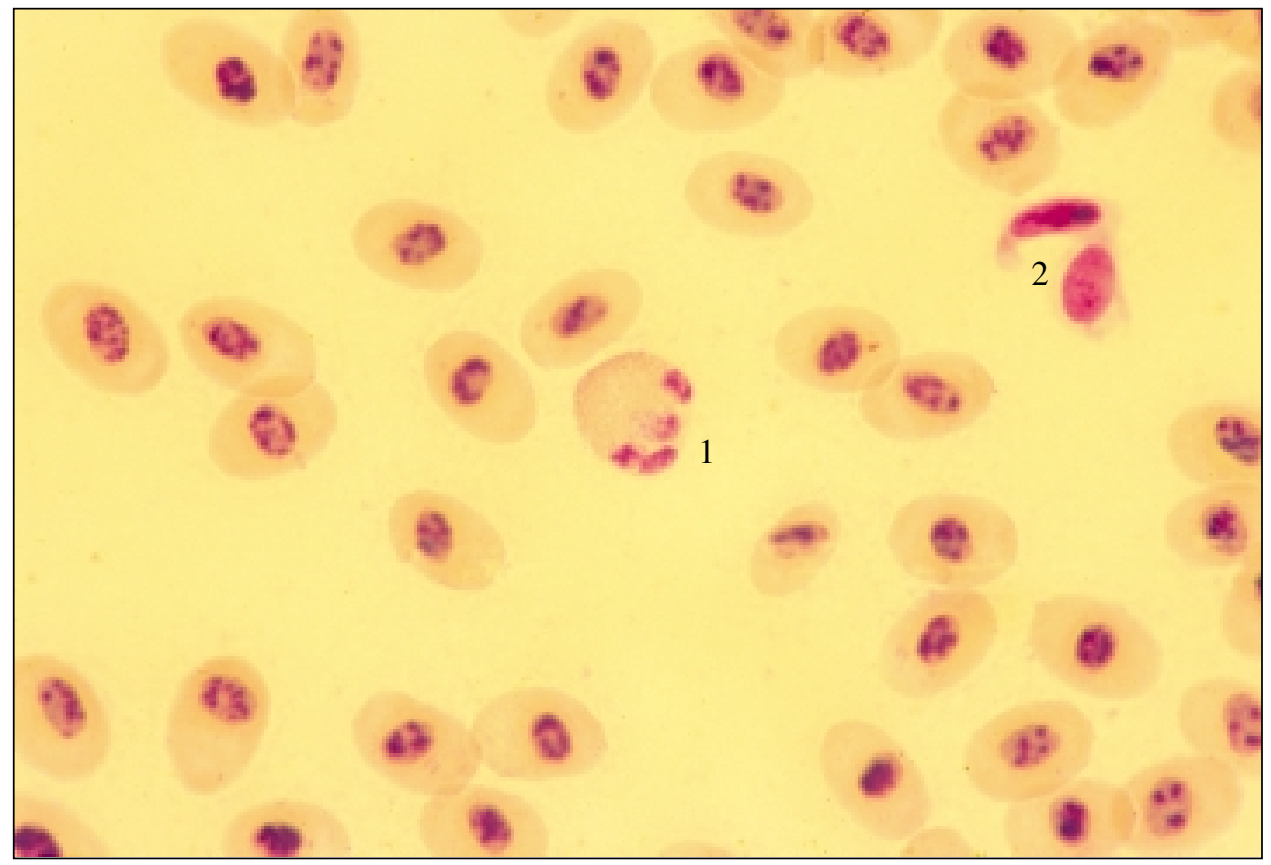

Fig. 5. Acipenser baerii. Eosinophilic granulocyte with segmented nucleus (1) and two thrombocytes $(2), \times 1000$.

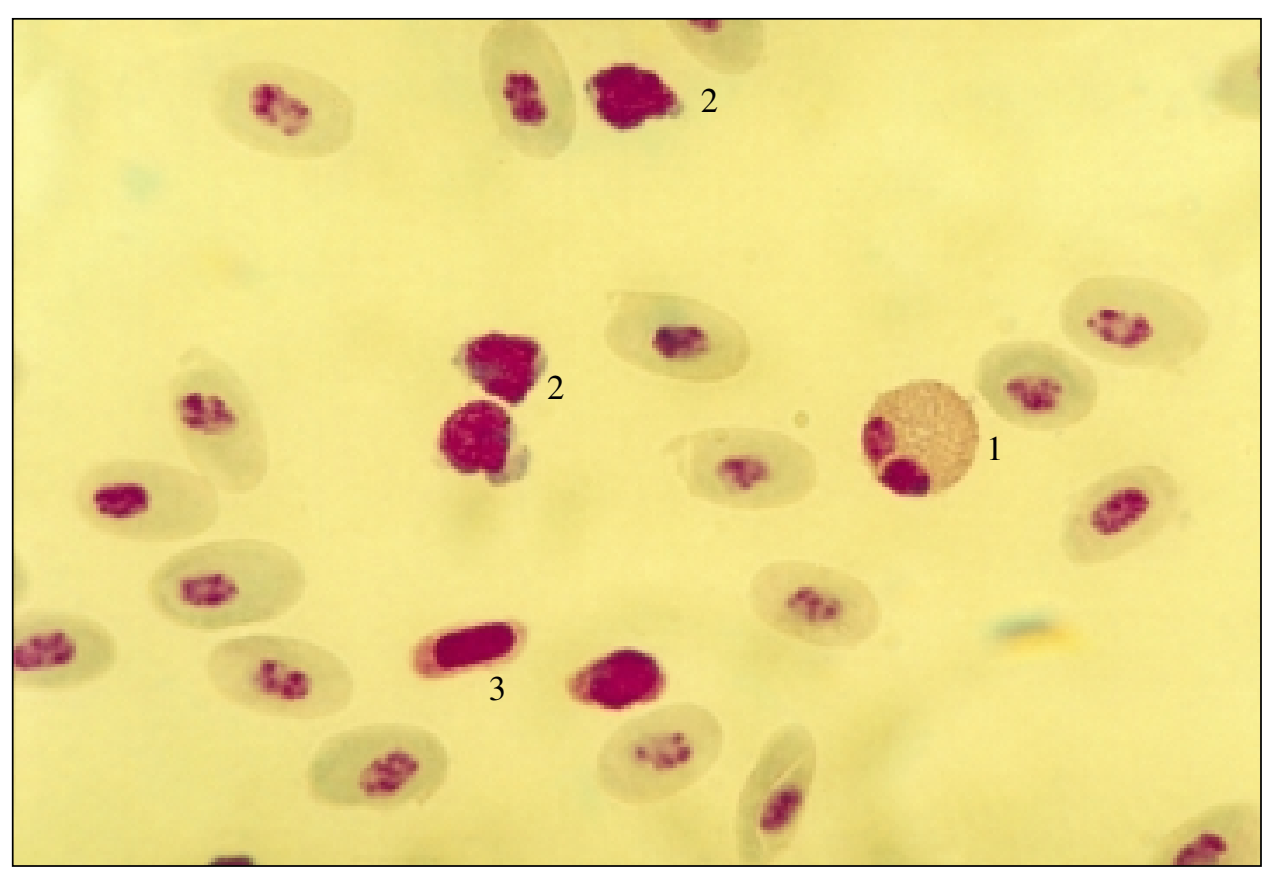

Fig. 6. Huso huso. Eosinophilic granulocyte with segmented nucleus (1), three lymphocytes (2) and two thrombocytes (3), $\times 1000$. 